living in low-pH areas, these reef-forming organisms will not fully adapt to the ocean acidification conditions expected by 2100 , say the authors.

Proc. Natl Acad. Sci. USA http://dx.doi.org/10.1073/ pnas.1301589110 (2013)

\section{BIOLOGY}

\section{A fluorescent protein from eels}

Muscle fibres of the Japanese freshwater eel (Anguilla japonica) produce a fluorescent protein, the first to be identified in a vertebrate.

Atsushi Miyawaki and his colleagues at the RIKEN Institute in Wako, Japan, identified the gene that encodes the protein and named it UnaG, after unagi, the Japanese word for this eel. When expressed in mammalian cells, the protein produced green fluorescence. UnaG is inactive until it binds to the naturally occurring small molecule bilirubin, a breakdown product of haemoglobin. The team showed that UnaG can be used to measure bilirubin in human \& serum. It might also be useful as a laboratory tool alongside other widely used fluorescent proteins.

Cell http://dx.doi.org/10.1016/ j.cell.2013.05.038 (2013)

For a longer story on this research, see go.nature.com/fljtrl

\section{ANIMAL BEHAVIOUR}

\section{Turtle tots chase warm spots}

Cold-blooded turtles move towards the most comfortable climes, even while they are still embryos.

Wei-Guo Du at the Chinese Academy of Sciences in Beijing

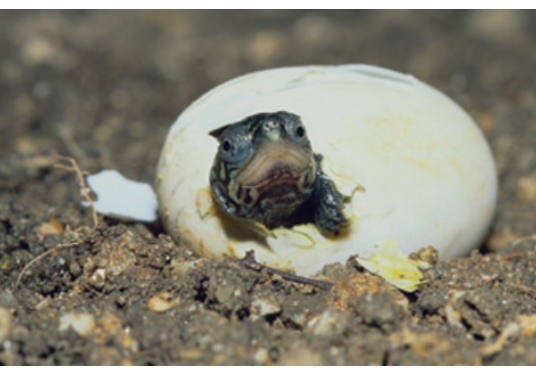

and his colleagues heated the ends or sides of recently laid eggs of the Chinese pond turtle (Chinemys reevesii, pictured) for a week and measured the movements of the embryos by shining light through the shells. Embryos moved towards spots maintained at a balmy $29^{\circ} \mathrm{C}$ or $30^{\circ} \mathrm{C}$, but shifted away from spots heated to a dangerously hot $33^{\circ} \mathrm{C}$. Only living embryos changed position, suggesting that the motion was due to the animals rather than to changes of viscosity in egg fluids. Although reptile embryos are generally thought to lack control over their environment, turtles inside eggs behave much like adults to regulate body temperatures, the authors say. Biol. Lett. 9, 20130337 (2013) For a longer story on this research see go.nature.com/8ixxah

\section{MARINE SCIENCE \\ Marine dumping detailed}

Humans are dumping far more litter in the ocean than was once thought.

Kyra Schlining at the Monterey Bay Aquarium Research Institute in Moss Landing, California, and her team used a database of characterized observations from 22 years of researchsubmersible missions in Monterey Bay to identify anthropogenic marine debris. The litter was seen in $1.49 \%$ of the surveyed area, was mainly metal and plastic, ranged in type and depth from a PVC pipe at 25 metres to a plastic bag at 3,971 metres, and was especially prevalent around the submarine Monterey Canyon. Most of the metal and plastic debris was seen below depths of 2,000 metres, suggesting that earlier studies may have underestimated the impact of detritus on deep regions, which are generally poorly observed. Submarine canyons may have trapped and funnelled the debris to depth, the authors suggest.

Deep-Sea Res. / http://dx.doi. org/10.1016/j.dsr.2013.05.006 (2013)

COMMUNITY CHOICE

The most viewed papers in science

\title{
Catalyst targets spot on carbon ring
}

\section{HIGHLY READ \\ on pubs.acs.org in May}

A metal catalyst makes sure that molecules join at the correct region of a carbon ring, disrupting the same bond every time.

Chemists have made strides in identifying reactions that disrupt notoriously unreactive carbon-hydrogen bonds, which is a key step when attaching molecules to carbon-ring structures. But it is still challenging to ensure that a molecule joins at the correct region of a ring. Frank Glorius and his colleagues at the University of Münster in Germany have solved this problem for a recalcitrant region on a class of rings known as benzo[ $b]$ thiophenes. Using palladium on a carbon support, together with copper chloride, the authors developed a catalyst with more than $99 \%$ selectivity for the desired hydrogen atom in many cases. The reaction is quite cheap, and withstands air and water.

J. Am. Chem. Soc. 135, 7450-7453 (2013)
NEUROBIOLOGY

Mutations alter brain amyloid

Some mutations that boost the risk of Alzheimer's may also increase production of a form of amyloid- $\beta$, a peptide that is thought to contribute to the disease.

People who inherit specific mutations of the genes PSEN1 or PSEN2 nearly always develop a rare form of Alzheimer's disease. Randall Bateman and his team at the Washington University in St. Louis, Missouri, used stable isotope labelling and positron emission tomography to track production of amyloid- $\beta$ in the brains (pictured) of 11 patients who carry PSEN mutations and 12 of their siblings who do not. Those with the mutation produced a long form of the peptide, called amyloid- $\beta 42$, at a rate $18 \%$ higher on average than those without the mutation.

Amyloid- $\beta 42$ is the main component of amyloid plaques, which are found in the brains of patients with Alzheimer's. Sci. Transl. Med. 5, 189ra77 (2013)
PALAEONTOLOG

\section{Early animals' revealing tracks}

Fossilized trails left in 560-million-year-old Canadian rocks may be some of the earliest evidence of squirming animals. Latha Menon at the University of Oxford, UK, and her team studied the disk-shaped impressions left by an organism called Aspidella in what was once shallow water in Newfoundland. The authors identified previously overlooked horizontal and vertical rock trails that seemed to be linked with Aspidella. They suggest that the marks were made as the animals wormed their way out of sediment, rather than as they passively slid. Aspidella, and perhaps other Ediacarans, were probably early animals living underwater, the authors say. Geology http://dx.doi. org/10.1130/G34424.1 (2013)

\section{$\rightarrow$ NATURE.COM}

For the latest research published by Naturevisit:

www.nature.com/latestresearch 